\title{
Psychological Empowerment and Job Satisfaction of Temporary and Part-Time Nonstandard Workers: A Preliminary Investigation
}

\author{
Kevin E. Dickson \\ Southeast Missouri State University \\ Alicia Lorenz \\ Southern Illinoisan
}

\begin{abstract}
This study examines several relationships between psychological empowerment and job satisfaction of temporary and part-time nonstandard workers. Data were collected from undergraduate students employed in short-term jobs outside their field of study. This study found two cognitions of psychological empowerment (meaning and impact) to be positively associated with job satisfaction. This study also tested the relationships between organizational tenure and psychological empowerment and organizational tenure and job satisfaction for temporary and part-time nonstandard workers. The results indicate a positive relationship between organizational tenure and psychological empowerment and a negative relationship between organizational tenure and job satisfaction.
\end{abstract}

\section{Introduction}

Nonstandard workers include temporary employees, part-time employees, and contracted employees (Davis-Blake, Broschak, \& George, 2003; Kalleberg, 2000; Kalleberg, Reskin, \& Hudson, 2000). These work arrangements are common in the U.S. economy (Befort, 2003), and Houseman and Polvika (2000) estimated nonstandard workers make up more than a quarter of the U.S. workforce. However, compared with research on standard work arrangements, research in this area is limited. Even though many nonstandard workers have less permanent work arrangements than their standard counterparts, the increasing presence of nonstandard workers in the U.S. and world economy (Allan, 2002; Broschak \& Davis-Blake, 2006; Connelly \& Gallagher, 2004) increases the importance of understanding their attitudes and determining how supervisors' actions may shape those attitudes.

The nonstandard workers included in this study are those in temporary and part-time work arrangements. Independent contractors are excluded from this study. Temporary and part-time nonstandard workers commonly work alongside standard workers in an organization's daily operations (Befort, 2003; Broschak \& Davis-Blake, 2006). They are likely to find themselves supervised by the management of the organization in which they are currently employed (Belous, 1989; Broschak \& Davis-Blake, 2006). Finally, they commonly have fewer skills and receive less compensation for their work (Kallenberg et al., 2000; Levenson, 2000; Welch, 1997). Independent contractors often consider themselves self-employed and experience job stability similar to employees with standard work arrangements (Connelly \& Gallagher, 2004; Houseman \& Polivka, 
2000). These attributes of independent contractors are uncommon for nonstandard workers in temporary and part-time work arrangements. Due to these significant differences, this paper excludes independent contractors and references to nonstandard workers refer to temporary and part-time nonstandard workers unless otherwise specified. This study focuses on two areas of interest related to temporary and parttime nonstandard workers.

The first of these two areas is job satisfaction for temporary and part-time nonstandard workers. Job satisfaction has been studied in the context of nonstandard workers (De Witte \& Naswall, 2003; Feldman, 1990; Feldman, Doerpinghaus, \& Turnley, 1995; Ellingson, Gruys, \& Sackett, 1998; Krausz, Brandwein, \& Fox, 1995; Lowry, Simon, \& Kimberley, 2002; Marler, Barringer, \& Milkovich, 2002; MacNamara, 2003), but most studies compare standard and nonstandard workers to determine who has higher job satisfaction in the workplace (Connelly \& Gallagher, 2004). Some research has determined selected antecedents of job satisfaction for nonstandard workers such as job security (De Witte \& Naswall, 2003; MacNamara, 2003), or the election by nonstandard workers to be in a nonstandard work arrangement rather than a standard work arrangement (Feldman, 1990; Krausz et al., 1995; Ellingson et al., 1998). This study focuses on actions taken by supervisors that may affect job satisfaction of nonstandard workers. The second of these two areas is psychological empowerment (Carless, 2004; Ozaralli, 2003; Spreitzer, 1995; Thomas \& Velthouse, 1990), which has not received adequate treatment in the area of nonstandard workers. This paper links psychological empowerment and job satisfaction for nonstandard workers.

The study also explores the effects of organizational tenure on temporary and part-time nonstandard workers. In conflicting studies, researchers (Donohue \& Heywood, 2004; Griffeth, Hom, \& Gaertner, 2000; Koys, 2001; Schneider, 1987) have argued both for higher job satisfaction and lower job satisfaction as tenure increases. This investigation of the tenure of nonstandard workers considers the question from the viewpoint of nonstandard workers and provides additional information in this ongoing debate. The study also investigates psychological empowerment and the organizational tenure of nonstandard workers.

\section{Job Satisfaction}

Three consequences of job satisfaction are significant for nonstandard workers and their supervisors. The first of these is a positive relationship between job satisfaction and performance. In past meta-analyses, researchers have argued that job satisfaction has only a weak positive link with performance (Brayfield \& Crockett, 1955; laffaldano \& Muchinsky, 1985). However, a more recent meta-analysis correcting for limitations in these prior meta-analyses has found a stronger, positive link between performance and job satisfaction than previously accepted (Judge, Thoresen, Bono, \& Patton, 2001). A positive link between performance and job satisfaction is an important outcome in any workplace and perhaps even more so for nonstandard workers who have fewer other formal ties to their workplace (Davis-Blake et al., 2003; Kalleberg, 2000; Kalleberg et al., 2000) that might increase their performance. 
The positive relationship between customer satisfaction and job satisfaction of employees is the second of these consequences (Griffith, 2001; Koys, 2001). It should be noted that researchers (Ryan, Schmit, \& Johnson, 1996; Koys, 2001) argue whether or not this is a reciprocal relationship; however, the nature of this relationship is not tested in this study. This positive relationship impacts this study of the job satisfaction of nonstandard workers, many of whom have interactions with customers, especially as part-time employees.

The third consequence of particular interest in the study of job satisfaction and nonstandard workers relates to the negative link between job satisfaction and turnover (Griffeth et al., 2000; Koys, 2001). While the link between job satisfaction and turnover may be of less interest for temporary employees, it is of significant interest for part-time employees in particular (Alexander, Nuchols, Bloom, \& Lee, 1995; Feldman, 1990; Tilly, 1992), where turnover can represent a significant challenge to an employer.

Many factors contribute to job satisfaction. Berta (2005) reported job satisfaction linked to experiencing positive relationships with co-workers, enjoying the work itself, approving of supervisors' performance, and having the freedom to participate in decision making. Jones (2005) reported that workers who felt they had a positive impact on others were the most satisfied. In addition, the amount of prestige that the outside world associates with a job can also be a factor of job satisfaction (Jones, 2005). Many of the factors mentioned above are not out of reach for nonstandard workers, although the conditions mentioned in these studies may not be common in nonstandard work settings. Many of these factors would not be cost prohibitive for organizations to implement if they improve the job satisfaction of temporary and parttime nonstandard workers. Organizations that hire nonstandard workers may face problems such as low productivity and high turnover rates. One way to combat these problems is to improve job satisfaction for temporary and part-time nonstandard workers (Griffeth et al., 2000; Judge etal., 2001; Koys, 2001).

\section{Psychological Empowerment}

Thomas and Velthouse (1990) describe a cognitive model of empowerment in which increased intrinsic task motivation is manifested in four cognitions: meaningfulness, competence, choice, and impact. The four cognitions relate to this study of nonstandard workers, since these cognitions may be influenced by a nonstandard worker's supervisor. The study explores which of these four cognitions have significant impact on the psychological empowerment of nons tandard workers.

This study uses Spreitzer's (1995) terminology of the four cognitions of psychological empowerment: meaning, competence, self-determination, and impact. Spreitzer (1995) renamed the meaningfulness cognition using instead the term meaning, defined as the value of a work goal or purpose judged in relation to an individual's own ideals or standards. This cognition involves a fit between the requirements of one's work role and one's values, beliefs, and behaviors. Self-determination is a n individual's sense of 
having control over how work is accomplished and is related to the choice cognition as put forth by Thomas and Velthouse (1990). Competence, or self-efficacy, is the belief that an employee is capable of performing work activities with skill. Finally, impact is the degree to which an individual can influence strategic, administrative, or operating outcomes at work (Spreitzer, 1995; Spreitzer, Kizilos, \& Nason, 1997). Spreitzer (1995) uses these cognitions to define psychological empowerment. She argues that the four cognitions combine additively to create an overall construct of psychological empowerment as "a motivational construct manifested in four cognitions" (Spreitzer, 1995, p. 1444). Psychological empowerment, which takes into account environmental influences, should not be confused with individually-oriented conceptions of empowerment, which view empowerment as a personality variable (Zimmerman, 1990).

\section{Hypotheses}

Psychological empowerment has been found to be significantly related to job satisfaction; however, the individual constructs have received varied results (Carless, 2004; Seibert, Silver, \& Randolph, 2004; Liden, Lucas, \& Sparrowe, 2000; Spreitzer et al., 1997). The meaning cognition has the most consistent results and has been found to be significantly related to psychological empowerment in studies with varying sample characteristics.

\section{Meaning}

Pratt and Ashforth (2003) describe meaning to be an employee's sense of their work as purposeful and significant. Thomas and Velthouse (1990) define meaning as the value of a task when compared to an individual's ideals or standards. Finally, Hackman and Oldham (1980) describe meaning as the fit between work requirements and beliefs, values, and behaviors. Temporary and part-time nonstandard workers, whose jobs may be of lower quality than standard work arrangements (Ferber \& Waldfogel, 1998; Kalleberg, 2000), may not have a strong expectation that their work will be purposeful or aligned with their values and beliefs.

However, researchers have argued that people can find meaning in almost any task, job, or organization (Ashforth \& Kreiner, 1999; Pratt \& Ashforth, 2003; Wrzesniewski, 2003). This may relate to the subjective nature of meaning (Pratt \& Ashforth, 2003). For example, meaning has been reported as supporting one's family, impacting an organization in a positive way, and expressing one's self through work (Colby, Sippola, \& Phelps, 2002). Wrzesniewski (2003) argues that individual employees define the meaning of their work. The many sources of meaning and the subjective nature of this cognition of psychological empowerment suggest that nonstandard workers can experience meaning at work.

In empirical studies, meaning has received strong support as being positively associated with job satisfaction. Spreitzer and colleagues (1997) used two separate samples to study the relationship between psychological empowerment and job satisfaction. The first sample group consisted of mid-level employees from a Fortune 
500 industrial organization that would be less likely to contain a high concentration of employees employed in work commonly assigned to temporary or part-time nonstandard workers. The second sample consisted of lower-level employees from an insurance company that may be more likely to have a significant number of employees that would be engaged in work that could be assigned to temporary and part-time nonstandard workers. Spreitzer and colleagues (1997) did not measure whether or not employees' work arrangements were standard or nonstandard.

In the first sample, meaning was related to work satisfaction and explained the most variance in work satisfaction (Spreitzer et al., 1997). In the second sample, the meaning cognition also explained significant variance in work satisfaction. Since the work assigned to the second sample is representative of the work that may be assigned to temporary and part-time nonstandard workers, this study suggests that meaning may be related to job satisfaction for nonstandard workers performing similar tasks. The study conducted by Spreitzer and colleagues (1997) does not establish that nonstandard workers would relate the meaning cognition of psychological empowerment to job satisfaction. The current study tests this relationship.

Carless (2004) used a sample of customer service employees to study psychological empowerment and job satisfaction. She found meaning to be significantly related to present job satisfaction, with meaning and competence being the most significant cognitions. Since Carless (2004) used customer service employees, her study also consisted of work that might be assigned to temporary and part-time nonstandard workers. Liden and colleagues (2000) studied employees in lower levels of several major divisions of a large service organization. They also found the meaning cognition of psychological empowerment to have a significant relationship with work (Liden et al., 2000). This sample also consisted of employees whose work may likely be assigned to temporary and part-time nonstandard workers.

Theoretical development has found that the meaning cognition of psychological empowerment may be experienced by nonstandard employees and empirical results have found meaning to be positively related to job satisfaction; therefore, we predict that meaning is positively associated with job satisfaction for nonstandard workers.

H1: The meaning cognition of psychological empowerment will be positively associated with job satisfaction for temporary and part-time nonstandard workers.

\section{$\underline{\text { Self Determination }}$}

Self-determination encompasses employees' sense of control over how their work is done. Staples (1990) argued that empowerment dealt with the efforts of individuals and groups to increase their control. Deci, Connell and Ryan (1989) describe this as being able to initiate and regulate personal behavior. In other words, employees with selfdetermination have some control over what they will do, how much effort they will put in, and when they will start and stop (Spector, 1986). Deci and Ryan (1987) presented self-determination as related to job satisfaction. Similarly, Thomas and Velthouse 
(1990) have argued that the element of self-determination is related to Hackman and Oldham's (1980) use of autonomy, and Ashforth (1990) argued that a lack of autonomy was associated with a lack of job satisfaction. Others have related self-determination with perceived control (Spreitzer et al., 1997).

However, some empirical studies point in the opposite direction. In their first sample, Spreitzer and colleagues (1997) found self-determination to be related to job satisfaction. However, this first sample of middle managers was less likely to involve work assignments that would be given to part-time or temporary nonstandard workers. In their second sample, where work assignments are more likely representative of assignments given to nonstandard workers, self-determination was not related to job satisfaction. This sample also reported a lower mean self-determination score. This study gives evidence that the self-determination cognition of psychological empowerment may not be related to job satisfaction for employees with work assignments that are more likely to be completed by temporary and part-time nonstandard workers.

The findings of Spreitzer and colleagues (1997) also align with the definition of selfdetermination considering the work assigned to many temporary and part-time nonstandard workers. Many part-time or temporary nonstandard workers would have at most significantly limited self-determination at work over matters that could lead to psychological empowerment or job satisfaction, since they have fewer skills, participate in less training, and receive lower compensation (Befort, 2003; Ferber \& Waldfogel, 1998; Kalleberg, 2000; Kallenberg et al., 2000; Levenson, 2000; Welch, 1997). This difference in the potential for self-determination between Spreitzer and colleagues' (1997) two studies may be a key in understanding why empirical findings relating selfdetermination to job satisfaction have been inconsistent.

Carless (2004) in her sample of customer service employees did not find selfdetermination to be significantly related to present job satisfaction. Her study may have included a significant number of employees involved in work of the type that may be assigned to nonstandard workers. Liden and colleagues (2000), in another sample likely to have included work that may be assigned to nonstandard workers, also did not find the self-determination cognition of psychological empowerment to have a significant relationship with work satisfaction.

Considering the theoretical definitions of self-determination, the nature of assignments often given to temporary and part-time nonstandard workers, and the empirical results described above, self-determination will not likely be positively associated with job satisfaction for the nonstandard workers in this sample.

H2: The self-determination cognition of psychological empowerment will not be positively associated with job satisfaction for temporary and part-time nonstandard workers. 


\section{Competence}

Competence at work has been defined as the ability to perform work skillfully when effort is put forth (Thomas \& Velthouse, 1990). Competence has been closely linked with self-efficacy (Spreitzer, 1995; Spreitzer et al., 1997; Thomas \& Velthouse, 1990). Researchers (Bandura \& Schunk, 1981; Gist, 1987) have suggested that personallydriven success at a task increases self-efficacy and satisfaction. Researchers (Gist, 1987; Harackiewicz, Sansone, \& Manderlink, 1985) have also argued that competence or self-efficacy is related to intrinsic motivation. Theories of self-efficacy have also suggested that an individual's mood may affect self-efficacy (Bandura, 1982; Gist, 1987; Gist \& Mitchell, 1992). Therefore, to the extent that attitudes such as job satisfaction affect moods, and since attitudes are accepted as less temporary than moods, job satisfaction may affect feelings of competence or self-efficacy through its effect on the individual's mood at work.

In Spreitzer and colleagues' (1997) second sample, which was more likely to have the type of work completed by nonstandard workers than the first, the competence cognition positively related to job satisfaction. In Carless' (2004) sample of customer service employees, which also had employees involved in work that may be assigned to nonstandard workers, she found competence to be significantly related to job satisfaction. Liden and colleagues (2000), in a study of employees involved in work commonly assigned to temporary and part-time nonstandard workers, found the competence cognition of psychological empowerment to have a significant relationship with work satisfaction. Therefore due to theoretical argument and empirical evidence, competence will be positively associated with job satisfaction for temporary and parttime nonstandard workers in this study, since it deals with whether or not employees are capable of performing their jobs.

H3: The competence cognition of psychological empowerment will be positively associated with job satisfaction for temporary and part-time nonstandard workers.

$\underline{\text { Impact }}$

Impact has been defined as the perception that one's behavior has an effect on one's task environment (Thomas \& Velthouse, 1990). Impact has also been defined as the perception of environmental resistance to personal impact regardless of ability (Thomas \& Velthouse, 1990). This is distinct from competence in which a person feels that they could perform if given the opportunity. It has also been differentiated from locus of control, which is more global in nature (Spreitzer, 1995; Thomas \& Velthouse, 1990). In terms of psychological empowerment, impact has been referred to as the converse of learned helplessness in a work setting (Spreitzer, 1995). Ashforth (1989) suggests that impact is the ability to influence work outcomes, whether strategic, administrative, or operational. The effect of impact on nonstandard workers is less clear than the other psychological empowerment cognitions. However, based on the nature of many temporary and part-time nonstandard work assignments (Ferber \& Waldfogel, 1998; 
Kalleberg, 2000), nonstandard workers with less skill and training would not likely experience impact over anything more than operational outcomes in most settings.

A lack of opportunity for impact at work has been found to be negatively related to employee satisfaction (Ashforth, 1989). Thomas and Tymon (1994) found that job satisfaction was related to impact at work. However, Spreitzer and colleagues (1997) did not find impact positively related to work satisfaction in either of their samples, including their second sample which was more likely to consist of the type of work completed by nonstandard workers. In her sample of customer service employees, Carless (2004) did find impact to be significantly related to present job satisfaction which measured the extent to which the job was intrinsically satisfying and was taskand job-specific, but did not find it related to general job satisfaction. Liden and colleagues (2000) did not find impact to be significantly related to job satisfaction. These mixed empirical findings provide an opportunity to test this relationship with temporary and part-time nonstandard workers.

Theory and mixed empirical results make it hard to determine whether or not the impact cognition of psychological empowerment will have a positive relationship with job satisfaction for nonstandard workers. Nonstandard workers generally will not expect significant impact at work due to the nature of their preparation (Befort, 2003; Ferber \& Waldofogel, 1998). However, given the opportunity to have perceived impact over operational outcomes, the most likely form of impact for temporary and part-time nonstandard workers, the impact cognition may play a role in the job satisfaction of these workers. Taking into account this possibility for impact and findings of significance between impact and present job satisfaction, we predict that for temporary and part-time nonstandard workers this cognition of psychological empowerment will be positively related with job satisfaction.

H4: The impact cognition of psychological empowerment will be positively associated with job satisfaction for temporary and part-time nonstandard workers.

\section{Organizational Tenure and Job Satisfaction}

Schneider (1987) argued for a positive relationship between tenure and job satisfaction suggesting that those who fit in an organization are more likely to be satisfied and have longer organizational tenure. Other researchers have similarly argued that job satisfaction and voluntary turnover, which reduces organizational tenure, are negatively related (Griffeth et al., 2000; Koys, 2001). However, Donohue and Heywood (2004) using a sample of over 6000 males and females ranging in age from 23 to 31 found a negative relationship between tenure and job satisfaction, but they indicated the potential for a U-shaped relationship underlying their results. The negative relationship found in their study between tenure and job satisfaction could also be evidence for a lack of psychological empowerment over time leading to greater dissatisfaction as tenure increases. This study tests this possibility by controlling psychological empowerment while testing the relationship between organizational tenure and job satisfaction. 
Temporary and part-time nonstandard workers should have sufficient mobility to exit a work setting where job satisfaction is low. An unsatisfied part-time or temporary nonstandard worker is likely to look for employment elsewhere, since many such positions are of shorter duration (Allan, 2002; Befort, 2003; Belous, 1989; Houseman \& Polivka, 2000; Nollen \& Axel, 1996) and are not career-building positions (Befort, 2003; Belous, 1989; Farber, 2000). In general, temporary and part-time nonstandard workers have less to lose by switching employers. Therefore, nonstandard workers who have been with the same company for an extended period of time should report higher job satisfaction.

H5: The organizational tenure of a temporary or part-time nonstandard worker will be positively associated with that employee's job satisfaction.

\section{Organizational Tenure and Psychological Empowerment}

Whether the organizational tenure of a nonstandard worker will affect psychological empowerment is worthy of empirical testing. Researchers (Koberg, Boss, Senjem, \& Goodman, 1999) have argued that employees with greater organizational tenure are more likely to experience feelings of empowerment. Ozaralli (2003) found that employees who have a longer tenure with their company feel more empowered than those with shorter organizational tenure and suggested that this increase in empowerment related to tenure was due to increased experience. However, the tenure in Ozaralli's (2003) study was longer than that common for many temporary and parttime nonstandard workers. Therefore, this test of nonstandard workers with shorter tenures can clarify the nature of this relationship when organizational tenure is shorter in duration.

The definitions of the four cognitions of psychological empowerment described earlier in this paper (Spreitzer, 1995; Thomas \& Velthouse, 1990) suggest the potential relationship between tenure and psychological empowerment. Based on the theoretical definition presented earlier, competence would likely increase with tenure. Impact, as the opportunity to have perceived impact over operational outcomes, would also likely increase with organizational tenure. One might argue that meaning would not increase with tenure for nonstandard workers, since at some level meaning is present or absent at the beginning of a job and does not vary significantly after the early period of employment. However, if meaning is determined by the individual employee and can be influenced by co-workers and supervisors (Pratt \& Ashforth, 2003; Wrzesniewski, 2003), then meaning may be malleable over time, and with greater understanding of one's work, it is possible that it might increase. This does not mean a decrease is not possible, but the mobility of temporary and part-time nonstandard workers suggests that if meaning decreases significantly over time, a nonstandard worker may find another position. Thus through the mechanism of attrition, the fit between an employee and their work environment would not be expected to decrease (Schneider, 1987). 
Self-determination may be the least likely of the psychological empowerment cognitions to increase for nonstandard workers. This cognition deals with control over the how work is done (Deci et al., 1989; Spector, 1986), and temporary and part-time nonstandard workers often lack this kind of control. However when trust is increased between an employee and supervisor, self-determination may increase. Thus increased levels of the psychological empowerment cognitions are predicted to be positively associated with increased organizational tenure for nonstandard workers.

H6: The organizational tenure of a temporary or part-time nonstandard worker will be positively associated with that employee's psychological empowerment.

\section{Methodology}

\section{$\underline{\text { Sample }}$}

The study's sample was made up of undergraduate students at a regional Midwestern university. This sample is appropriate for a preliminary investigation, since a university campus presents a significant grouping of temporary or part-time nonstandard workers from a variety of employers. Items in the questionnaire ensured appropriate selection of individuals who viewed themselves working as temporary and/or part-time nonstandard workers. A random sample of 1,500 students who live in the residence halls on-campus and 1,500 students who live off-campus were chosen to participate in the study. The sample was randomly determined from a list of students. This list was alphabetized, and students were chosen for the study using a regular interval to obtain the desired sample size. International students were not included in the sample because they have unique rules and regulations regarding employment in the United States.

Only students between the ages of 18 and 30 were included in the sample, since students within this age range would be most likely to hold a temporary or part-time nonstandard position. Many of the non-traditional students at the university used for this study are full-time employees taking classes to further their career and would not fit within the definition of temporary and part-time nonstandard workers. Belous (1989) reported that when taken as a percentage of the total workforce a higher percentage of younger employees are temporary workers. During sample selection, an equal number of male and female students were included in each group (on- and off-campus) in an effort to ensure significant representation of both genders in this study.

The students in the random sample received an e-mail asking them to complete the survey online. This e-mail informed students that their participation in the study was completely voluntary and that their responses would be anonymous and confidential. Of the 3,000 students who were contacted about the survey, 397 valid, usable survey responses were received. Any survey responses with duplicate contact information for the survey were removed; however, very few responses fell into this category. The response rate was approximately $13 \%$. 
To check for potential non-response bias due to the low response rate, the demographics of the sample were compared to the known demographics of students at the university. In the sample $62 \%$ of respondents were female and at the university $59 \%$ of the students were female. All but five percent of the students in the sample were the age of a traditional student. The information gathered on highest degree obtained (92\% pre-baccalaureate) also appeared to be as expected for this sample. A comparison of the characteristics of the sample to that of the population from which it was drawn is a relatively simple method for checking for non-response bias, but since no significant concerns were raised by this analysis, no further analysis was completed.

\section{Questionnaire}

Data were collected using an online questionnaire that measured psychological empowerment and job satisfaction. Respondents provided information regarding job tenure as well as demographic information such as gender, age, and education level which was used to check for non-response bias and as control variables. Information about their immediate supervisor was also collected.

\section{Nonstandard Worker Classification}

Two questions were asked to determine whether the respondent's current job was a position that could be the start of their career or if it was a temporary job held while studying toward a degree and thus either temporary or part-time nonstandard in nature. The first question asked, "Is your current job in your field of study?" The second asked respondents to classify their current employment as short-term or long-term.

Respondents with jobs not in their field of study who viewed these positions as shortterm are likely to think of their job as nons tandard work. These positions are viewed as non career-related and fill the need to pay the bills until a better, career-related position can be found.

Among the respondents, $77 \%$ said the job they held currently was not in their field of study, and $81 \%$ viewed their current employment as short-term. We retained only respondents who stated that their work was not in their field of study and short-term in nature, since these respondents were most likely to view themselves as part-time or temporary nonstandard workers. This reduced usable responses to 262, but this subsample reflects the most representative test of the views of temporary and part-time nonstandard workers given the sample collected. The robustness of the results was tested using the entire sample, and the only difference in the outcomes for the hypotheses was that self-determination was positively associated with job satisfaction when the entire sample was included.

This method of classification of an employee's work as nonstandard or standard allowed the respondent to make this determination based on their own perceptions. This method aligns with our interest in employees' perceptions of their work rather than the definition of their work from an external point of view. Information regarding the variables below is based on the retained sample of 262 respondents. 


\section{Dependent Variables}

This section details the two dependent variables used to test the hypotheses in this study: job satisfaction and psychological empowerment.

Job Satisfaction

Job satisfaction was assessed using the Managerial Job Satisfaction Questionnaire developed by Cellucci and DeVries (1978), using a seven-point Likert scale, with "1" representing "Strongly Disagree" and "7" representing "Strongly Agree." This scale measures job satisfaction in five categories: satisfaction with pay, promotions, coworkers, supervisors, and the work itself. Eight of the items were reverse coded as used by Viswesvaran, Deshpande, and Joseph (1998). Overall job satisfaction was determined by averaging the score for each question. The reliability for this scale using Cronbach's Alpha was .88.

\section{Psychological Empowerment}

The four cognitions of psychological empowerment were measured using the scales developed by Spreitzer (1995). Each of the four cognitions was measured with three questions using a seven-point Likert scale with 1 representing "Strongly Disagree" and 7 representing "Strongly Agree." Sample questions include: "The work I do is very important to me" (meaning), "I am confident about my ability to do my job" (competence), "I have significant autonomy in determining how I do my job" (selfdetermination), and "My impact on what happens in my department is large" (impact). The scale was found to be reliable in this study, and the alphas for each of the four cognitions were: meaning (.83), self-determination (.70), competence (.76), and impact (.82). Other studies (Carless, 2004; Spreitzer, 1995; Spreitzer, 1996; Spreitzer et al., 1997) have also found the self-determination cognition to have the lowest reliability of the four psychological empowerment cognitions. Thus the results for this cognition should be viewed with more caution than those with higher alphas. The overall psychological empowerment score was also found to be reliable $(a=.85)$.

\section{$\underline{\text { Independent Variables }}$}

This section details the two independent variables used to test the hypotheses in this study: psychological empowerment and organizational tenure.

\section{Psychological Empowerment}

Spreitzer's (1995) scale measures psychological empowerment, using three questions for each of the four cognitions of psychological empowerment: meaning, selfdetermination, competence, and impact. 


\section{Organizational Tenure}

Organizational tenure was measured by asking respondents to choose the length of time that they had remained with their current or most recent employer. The choice ranged from less than six months $(21 \%)$ to greater than three years. About $56 \%$ of the respondents had been employed by their current employer for one year or less. Another $25 \%$ had been employed between one and two years. Therefore, $81 \%$ of the respondents had been with their company two years or less. Houseman and Polivka (2000) also reported this tendency toward shorter tenure for nonstandard workers.

\section{Control Variables}

This section details the control variables used in this study: gender, age, education level, and level of manager.

\section{Gender}

Gender was measured using a simple dichotomous question. The sample was $62 \%$ female, indicating that females included in the random sampling responded at a higher rate than male members of the sample. This suggests that women were more likely to take the time to fill out the survey or that they were more likely to fit the qualifications in place to be included in the sample, such as filling out the survey correctly and identifying their work as short-term and not in their field of study.

Age

Age was controlled for because Spreitzer (1996) suggested that age might be related to psychological empowerment and because older nonstandard workers with more experience may feel more empowered through a greater sense of competence. It is also possible that age could affect job satisfaction if an older individual felt less satisfied working in a temporary or part-time nonstandard position than a younger individual. Respondents were asked to choose from a list of ranges that were grouped in three year increments. Most respondents (57\%) were in the 18 to 20 year age group, followed by $37 \%$ between 21 and 23 years. About $3 \%$ were between 24 and 26 years and only about $2 \%$ were between 27 and 29 years old.

\section{Education Level}

The respondents' highest level of education was found by asking them to select the highest level of education that they had completed. Their choices included: High School Diploma/GED (77\%), Associates Degree (15\%), Bachelors Degree (5\%), Masters Degree $(0 \%)$, and Other (3\%). Education level was controlled for due to Spreitzer's (1996) finding that it may be related to psychological empowerment, since workers who are well-educated may feel more competent. Well-educated employees might also be less satisfied working as temporary or part-time nonstandard workers. 


\section{Level of Manager}

The level of the respondent's manager was self-reported. Respondents were asked to choose the level of their supervisor from three options: lower-level manager (i.e. Supervisor, Coordinator) which was selected by $31 \%$ of the respondents, mid-level manager (i.e. Manager, Director) which was selected by $61 \%$ of the respondents, or top-level manager (i.e. Vice-President, President, CEO) which was selected by just under $9 \%$ of the respondents. This variable was not included in the statistical analyses, but supports the sample's status as comprised of nonstandard workers, since nonstandard workers are less likely to report to top-level managers in all but the smallest organizations.

\section{Results}

Table 1 gives the mean, standard deviation, and a correlation matrix for all variables included in the analyses. The hypotheses were tested by OLS regression. A summary of all hypotheses tested and the results of each test are given in Table 2. See model 1 in Table 3 for a regression analysis containing only control variables for comparison to the full model testing the hypotheses. Model 2 in Table 3 contains the statistical analysis for Hypotheses 1-5. The F-test for this model, using job satisfaction as the dependent variable, was $19.404(\mathrm{p}<.001)$.

Hypothesis 1 stated that the meaning cognition of psychological empowerment would be positively associated with job satisfaction. This hypothesis was supported. This can be interpreted to mean that nonstandard workers report higher satisfaction when their work goals align with their own ideals and standards. This test, as all others in this study, does not determine causality of the relationship, but only that these two items are positively associated with each other.

Hypothesis 2 was supported because the self-determination cognition was not positively associated with job satisfaction for this sample. This may be because temporary and part-time nonstandard workers do not expect significant control over how their work is done; however, the mean of 4.72 (standard deviation of 1.29) on a seven-point scale shows that most respondents felt a moderate level of self-determination. Perhaps this result is in part due to this sample of college students viewing their positions as temporary jobs not in their fields. Consequently, it may be that this sample was not empowered by this level of self-determination because they viewed their work arrangement as temporary and primarily for paying bills, since it was not in their field of work.

Caution should be taken when interpreting a non-significant result, as it may be due to a flaw in the research methodology and non-significant results are not as valuable as significant results in general. However, since the reliability of the scale is acceptable (although the lowest of the four cognitions), and other cognitions have been found to be significant, this result warrants consideration. 
Table 1: Descriptive Statistics and Correlation Matrix

\begin{tabular}{|l|l|l|l|l|l|l|l|l|c|}
\hline Variable & $\mathrm{N}$ & Mean & S.D. & 1 & 2 & 3 & 4 & 5 \\
\hline 1 & Meaning & 262 & 4.48 & 1.49 & & & & & \\
\hline 2 & $\begin{array}{l}\text { Self- } \\
\text { determination }\end{array}$ & 262 & 4.72 & 1.29 & $.58^{\star *}$ & & & & \\
\hline 3 & Competence & 262 & 6.01 & 0.95 & $.25^{\star *}$ & $.30^{\star *}$ & & & \\
\hline 4 & Impact & 258 & 4.24 & 1.51 & $.50^{\star *}$ & $.55^{\star *}$ & $.22^{\star *}$ & & \\
\hline 5 & $\begin{array}{l}\text { Psychological } \\
\text { Empowerment }\end{array}$ & 262 & 4.88 & 1.00 & $.82^{\star *}$ & $.81^{* *}$ & $.52^{\star *}$ & $.80^{* *}$ & \\
\hline 6 & $\begin{array}{l}\text { Job } \\
\text { satisfaction }\end{array}$ & 262 & 4.33 & 0.97 & $.54^{\star *}$ & $.43^{\star *}$ & $.21^{\star *}$ & $.44^{\star *}$ & $.56^{\star *}$ \\
\hline 7 & Tenure & 262 & 3.42 & 1.99 & .04 & .08 & .07 & $.19^{\star *}$ & $.13^{*}$ \\
\hline 8 & Gender & 262 & 0.62 & 0.49 & $.20^{\star *}$ & $.16^{*}$ & $.13^{*}$ & .02 & $.16^{*}$ \\
\hline 9 & Age & 262 & 1.51 & 0.68 & -.06 & -.03 & .10 & -.05 & -.03 \\
\hline 10 & $\begin{array}{l}\text { Education } \\
\text { Level }\end{array}$ & 262 & 1.37 & 0.84 & -.01 & -.07 & .02 & -.02 & -.03 \\
\hline
\end{tabular}

\begin{tabular}{|l|l|l|l|l|l|}
\hline \multicolumn{2}{|l|}{ Variable } & 6 & 7 & 8 & 9 \\
\hline 1 & Meaning & & & & \\
\hline 2 & $\begin{array}{l}\text { Self- } \\
\text { determination }\end{array}$ & & & & \\
\hline 3 & Competence & & & & \\
\hline 4 & Impact & & & & \\
\hline 5 & $\begin{array}{l}\text { Psychological } \\
\text { Empowerment }\end{array}$ & & & & \\
\hline 6 & $\begin{array}{l}\text { Job } \\
\text { satisfaction }\end{array}$ & & & & \\
\hline 7 & Tenure & $-.15^{\star}$ & & & \\
\hline 8 & Gender & $.14^{*}$ & .02 & & \\
\hline 9 & Age & $-.12^{*}$ & $.22^{* *}$ & -.04 & \\
\hline 10 & $\begin{array}{l}\text { Education } \\
\text { Level }\end{array}$ & -.11 & $.15^{*}$ & -.07 & $.21^{\star *}$ \\
\hline
\end{tabular}

${ }^{* *}$ Correlation is significant at the 0.01 level (2-tailed).

* Correlation is significant at the 0.05 level (2-tailed). 
Table 2: Summary of Hypotheses

\begin{tabular}{|l|l|l|}
\hline Number & Hypothesis & Findings \\
\hline H1 & $\begin{array}{l}\text { The meaning cognition of psychological } \\
\text { empowerment will be positively associated with job } \\
\text { satisfaction for temporary and part-time } \\
\text { nonstandard workers. }\end{array}$ & $\begin{array}{l}\text { Hypothesis } \\
\text { supported }\end{array}$ \\
\hline H2 & $\begin{array}{l}\text { The self-determination cognition of psychological } \\
\text { empowerment will not be positively associated with } \\
\text { job satisfaction for temporary and part-time } \\
\text { nonstandard workers. }\end{array}$ & $\begin{array}{l}\text { Hypothesis } \\
\text { supported }\end{array}$ \\
\hline H3 & $\begin{array}{l}\text { The competence cognition of psychological } \\
\text { empowerment will be positively associated with job } \\
\text { satisfaction for temporary and part-time } \\
\text { nonstandard workers. }\end{array}$ & $\begin{array}{l}\text { Hypothesis not } \\
\text { supported }\end{array}$ \\
\hline H4 & $\begin{array}{l}\text { The impact cognition of psychological } \\
\text { empowerment will be positively associated with job } \\
\text { satisfaction for temporary and part-time } \\
\text { nonstandard workers. }\end{array}$ & $\begin{array}{l}\text { Hypothesis } \\
\text { supported }\end{array}$ \\
\hline H5 & $\begin{array}{l}\text { The organizational tenure of a temporary or part- } \\
\text { time nonstandard worker will be positively } \\
\text { associated with that employee's job satisfaction. }\end{array}$ & $\begin{array}{l}\text { Hypothesis not } \\
\text { supported }\end{array}$ \\
\hline H6 & $\begin{array}{l}\text { The organizational tenure of a temporary or part- } \\
\text { time nonstandard worker will be positively } \\
\text { associated with that employee's psychological } \\
\text { empowerment. }\end{array}$ & $\begin{array}{l}\text { Hypothesis } \\
\text { supported }\end{array}$ \\
\hline
\end{tabular}

Table 3: OLS Regression for Dependent Variable Job Satisfaction

\begin{tabular}{|l|c|c|}
\hline Variable & $\mathbf{1}$ & $\mathbf{2}$ \\
\hline Meaning & & $.347^{\star \star \star}(.042)$ \\
\hline Self-determination & & $.091(.050)$ \\
\hline Competence & & $.054(.054)$ \\
\hline Impact & & $.234^{\star \star \star}(.041)$ \\
\hline Organizational Tenure & & $-.201^{\star \star *}(.026)$ \\
\hline Gender & $.126^{\star}(.122)$ & $.045(.103)$ \\
\hline Age & $-.100(.090)$ & $-.036(.075)$ \\
\hline Education Level & $-.080(.072)$ & $-.053(.059)$ \\
\hline $\mathrm{N}$ & 261 & 257 \\
\hline F-Test & $3.403^{*}$ & $19.404^{\star * *}$ \\
\hline Adjusted R Square & .027 & .364 \\
\hline
\end{tabular}

$\dagger p<.10,{ }^{*} p<.05,{ }^{* *} p<.01,{ }^{* * *} p<.001$. Beta coefficients are standardized. Standard errors are given in parentheses. 
Hypothesis 3 was not supported as the competence cognition was not found to be positively related to job satisfaction in this analysis. The reason for this could be that the respondents in this sample feel that they are capable of skillfully performing their tasks in their nonstandard work arrangements. The mean for competence was 6.01 and the standard deviation was .95 on a seven-point scale. The median was 6.33 with only four of 262 respondents reporting a competence level of less than the midpoint of four on the seven-point scale. The mode was seven on the scale with 60 respondents reporting a seven for the competence cognition. These statistics support the idea that most respondents felt competent and with such low variance and a high mean, it could be expected that competence would not be positively related to job satisfaction.

The impact cognition was positively associated with job satisfaction; therefore, Hypothesis 4 was supported. This result likely relies on the opportunity to have influence over primarily operational outcomes at work. All three of the items used by Spreitzer (1995) referenced the department in which the respondent worked, and so it is not unlikely that the respondents were referring to operational impact within their own department.

Hypothesis 5, which stated that organizational tenure would be positively associated with job satisfaction, was not supported (see model 2 in Table 3). In fact, organizational tenure was actually found to be negatively associated with job satisfaction. This result may be in part because the sample is made up of undergraduate nonstandard workers. College undergraduates may not expect to stay in a nonstandard work arrangement for a long period of time. They may become less satisfied over time because their nonstandard position will not advance their career. Respondents may also have taken a job they initially disliked for the income it provided.

Table 4: OLS Regression for Dependent Variable Psychological Empowerment

\begin{tabular}{|l|c|c|}
\hline \multicolumn{1}{|c|}{ Variable } & $\mathbf{1}$ & $\mathbf{2}$ \\
\hline Organizational Tenure & & $.211^{* * *}(.026)$ \\
\hline Job Satisfaction & $.559^{\star * *}(.054)$ & $.584^{* * *}(.052)$ \\
\hline Gender & $.086 \dagger(.106)$ & $.076(.103)$ \\
\hline Age & $.040(.077)$ & $.000(.076)$ \\
\hline Education Level & $.025(.063)$ & $.005(.061)$ \\
\hline $\mathrm{N}$ & 261 & 261 \\
\hline F-Test & $31.196^{* \star *}$ & $29.814^{\star * *}$ \\
\hline Adjusted R Square & .316 & .356 \\
\hline
\end{tabular}

$t p<.10,{ }^{*} p<.05,{ }^{* *} p<.01,{ }^{* * *} p<.001$. Beta coefficients are standardized. Standard errors are given in parentheses.

Model 1 in Table 4 presents the regression analysis for testing Hypothesis 6 with only control variables for comparison with the full model. See model 2 in Table 4 to view the statistical analysis for Hypothesis 6 . The dependent variable in this model was psychological empowerment and the F-test for the model was $29.814(p<.001)$. 
Hypothesis 6 tested whether organizational tenure would be positively associated with psychological empowerment. This hypothesis was supported even with job satisfaction controlled for in the model (see model 2 in Table 4). Thus psychological empowerment is positively related to tenure even though job satisfaction is negatively related as found in the test of Hypothesis 5.

\section{Discussion}

\section{Contributions to the Literature}

The results for the four cognitions of psychological empowerment on the job satisfaction of temporary and part-time nonstandard workers may not have emerged as might have been anticipated prior to this study. Both the meaning and impact cognitions of psychological empowerment were positively related with job satisfaction for temporary and part-time nonstandard workers. Either of these cognitions could be dismissed as unlikely sources of psychological empowerment for these types of workers. However as previously mentioned, Pratt and Ashforth (2003) argued that meaning is subjective and Wrzesniewski (2003) argued that individual employees may define the meaning of their work. These arguments may explain how this cognition could have played a role in the job satisfaction of the employees included in this sample. The finding that impact was positively related with job satisfaction, provides support that the perception of impact over one's work can be important in the workplace, even for temporary and part-time nonstandard workers who may not have high expectations for their opportunities to impact their workplace. It is likely that they perceive impact primarily over local, operational outcomes. On the other hand, due to high self-reported levels of selfdetermination and competence, these cognitions were not positively related to job satisfaction. These findings contribute to the literature on temporary and part-time nonstandard workers by beginning to address how their perceptions and attitudes are formed. The unanticipated nature of the findings for these relationships indicates the importance of this type of research inquiry, which has not been the focus of this area of the literature.

This study also adds to the literature studying temporary and part-time nonstandard workers by allowing employees to identify themselves as fitting into this category as described earlier in the methodology section of the paper. Arguments could be made that employees' perceptions of their positions are not as important as their organizational classifications. However, it may be that this perception plays an important role, since employees may act upon their perception of their classification. In either case, this study adds to the literature by introducing and using this method of classification.

The amount of time a nonstandard worker has been with the same company was found to be positively associated with psychological empowerment but negatively associated with job satisfaction. This unexpected finding, since psychological empowerment and job satisfaction are positively related to each other, raises questions about the nature of 
these relationships for temporary and part-time nonstandard workers. This adds to the literature for studies of these types of nonstandard workers.

\section{Practical Implications}

The results of this study should not be interpreted to mean that supervisors of nonstandard workers should not work to increase all four cognitions of psychological empowerment for their employees. However, they could especially concentrate on the meaning and impact cognitions if they want nonstandard workers to feel more job satisfaction through the process of psychological empowerment. One way to increase meaning would be to set clear goals that do not contradict the employees' values. Another way would be to make sure employees know how they fit into the big picture of the organization. Showing employees how their jobs fit into the organization and how the tasks they complete affect the outcomes of the company may increase their perception of meaning. Impact could be increased by giving temporary and part-time nonstandard workers processes by which they can suggest operational changes in their work environment. Such suggestion programs have been used by companies in the past with full-time employees.

Since, organizational tenure was positively associated with psychological empowerment but negatively associated with job satisfaction, a manager might balance this effect by giving incentives to employees who have been working for the company for a longer period of time in a nonstandard work arrangement to maintain a high level of job satisfaction. Possible rewards could be flexible scheduling, increased responsibility, gift certificates, raises, or others based on individual preference. These rewards should be cost-effective for the position held by the nonstandard worker.

\section{Limitations}

There are significant limitations to this study. First, self-reported data has the potential of mono-method bias. Although the study could have been improved through inclusion of input from other sources, the effects of this limitation are mitigated by the nature of the research questions. For example, employees are the best source of information concerning their own level of job satisfaction and psychological empowerment.

A second limitation was that the sample consisted of undergraduate students. Other samples of nonstandard workers might lead to different outcomes because undergraduate students or "nonstandard student workers" might be more educated and have different expectations of their nonstandard work arrangements. This potential difference between "nonstandard student workers" and other nonstandard workers could be an area for future research. The cross-sectional design of the study was another limitation. A longitudinal study would have provided opportunities to test the results over time and explore the causality of the observed relationships.

The argument could be made that since this study's sample consists of individuals with relatively short organizational tenure (just over $80 \%$ of the sample had organizational 
tenure of two years or less), a restriction of range exists that will bias the results of the organizational tenure hypotheses. While this restriction of range is a valid criticism, many nonstandard workers have short tenures within the range of the data collected for this study (Allan, 2002; Befort, 2003; Belous, 1989; Houseman \& Polivka, 2000; Nollen \& Axel, 1996). This study's results may not generalize to settings in which longer tenures are common for temporary and part-time nonstandard workers. However, studies of shorter periods of organization tenure have a place in the study of temporary and part-time nonstandard workers, since shorter tenures are common for many of these employees.

\section{Future Research}

To overcome some of these limitations, future research on nonstandard workers could use varied samples to determine whether results vary according to sample demographics. Future research could also include additional data from third party sources such as co-workers, managers or even organizational-level data. Co-workers could provide information regarding the behaviors of the nonstandard worker. Managers could provide insight by sharing productivity levels and absenteeism data. Data from the organization could be used to determine if an employee remains employed after a given time period. Nonstandard workers' levels of job satisfaction or psychological empowerment could then be compared to actual turnover rates. Organizational data could also be used to determine if employees who report high levels of psychological empowerment and/or job satisfaction are beneficial to the company by improving profits, customer retention rates, etc. It is also important to consider the causality of the relationships tested in this study, to determine if the cognitions lead to the attitudes, vice versa, or if a reciprocal relationship has the most explanatory power.

Another area for future research is the non-significant result for the gender control variable. Even though his control variable was not within the scope of the study, it is unexpected that once the variables of interest were included gender was not significantly related to the dependent variables. This lack of significance deserves additional study, since gender was significantly correlated with most of the variables in the study.

The non-significant findings for self-determination (as expected) and for competence (not as expected) could be explored in future studies, especially since the overall means of self-determination and competence were highest in this study. Therefore, the lack of psychological empowerment was not likely due to a lack of self-determination or competence as might be expected, but due to factors not included in this study, such as the nonstandard workers' expectations for their work arrangements or the outcomes they desire at work. These findings warrant future research, especially considering that when the entire sample was used, including those who identified their work as long-term and within their field of study, self-determination became significantly related to job satisfaction. It could be that alignment between the position and an employee's expectations might explain why cognitions of psychological empowerment were not 
significant in this study. If so, when or how self-determination and/or competence could be associated with high levels of job satisfaction for temporary and part-time nonstandard workers could be studied.

The negative relationship between organizational tenure and job satisfaction of nonstandard workers is another potential area for additional investigation. This may be due to the nature of this sample and the expectations of undergraduate students to exit nonstandard work arrangements relatively quickly. It could also be related to the majority of the respondents' short organizational tenure of two years or less. This finding deserves further study. Why, when tenure is longer, is psychological empowerment higher and job satisfaction lower given that psychological empowerment and job satisfaction are positively related?

Finally, to what extent an employee's perception of the psychological empowerment cognition of meaning may be affected by the influence of supervisors or co-workers could be another area for future research. Wrzensniewski (2003) questions how supervisors and peers might help facilitate the creation of meaning by employees, and Pratt and Ashforth (2003) argue that powerful organizational actors can influence employees' perceptions of the meaningfulness of their work. How much can an employee's perception of meaning be altered by determining what is important to the employee and indicating how the work performed aligns with the employee's priorities and values?

\section{Conclusion}

Nonstandard workers are a significant subset of the working population. Findings from studies that use samples of managers or full-time employees that are not nonstandard workers may not be applicable to this group. This study has found only two of the four cognitions of psychological empowerment (meaning and impact) to be positively associated with job satisfaction. In addition this study found that tenure has a positive relationship with psychological empowerment but a negative relationship with job satisfaction. These results have implications for the managers of nonstandard workers and proper training could be provided to supervisors so they can maximize the level of psychological empowerment and job satisfaction of employees with this increasingly common type of organizational relationship, since improving the productivity and retention of these workers may have a significant impact on the performance of a supervisor's workgroup and even the organization as a whole.

\section{References}

Alexander, J., Nuchols, B., Bloom, J., \& Lee, S. (1995). Organizational demography and turnover: An examination of multiform and nonlinear heterogeneity. Human Relations, 48(12), 1455-1480. 
Allan, P. (2002). The contingent workforce: Challenges and new directions. American Business Review, 20(2), 103-110.

Ashforth, B. E. (1989). The experience of powerlessness in organizations. Organizational Behavior and Human Decision Processes, 43(2), 207-242.

Ashforth, B. E. (1990). The organizationally induced helplessness syndrome: A preliminary model. Canadian Journal of Administrative Sciences, 7, 30-36.

Ashforth, B. E., \& Kreiner, G. E. (1999). "How can you do it?": Dirty work and the challenge of constructing a positive identity. Academy of Management Reviews 24(3), 413-434.

Bandura, A. (1982). Self-efficacy mechanism in human agency. American Psychologist, $37(2), 122-147$.

Bandura, A., \& Schunk, D. H. (1981). Cultivating competence, self-efficacy, and intrinsic interest through proximal self-motivation. Journal of Personality and Social Psychology, 41(3), 586-598.

Befort, S. D. (2003). Revisiting the black hole of workplace regulation: A historical and comparative perspective of contingent work. Berkeley Journal of Employment and Labor Law, 24(1),153-179.

Belous, R. S. (1989). The Contingent Economy: The Growth of the Temporary, Parttime, and Subcontracted Workforce. Washington D.C.: National Planning Association.

Berta, D. (2005). Put on a happy face: High morale can lift productivity. Nation's Restaurant News, 39(20), 8-10.

Brayfield, A. H., \& Crockett, W. H. (1955). Employee attitudes and employee performance. Psychological Bulletin, 52, 396-424.

Broschak, J. P., \& Davis-Blake, A. (2006). Mixing standard work and nonstandard deals: The consequences of heterogeneity in employment arrangements. Academy of Management Journal, 49(2), 371-393.

Carless, S. A. (2004). Does psychological empowerment mediate the relationship between psychological climate and job satisfaction? Journal of Business and Psychology, 18(4), 405-425.

Cellucci, A. J., \& DeVries, D. L. (1978). Measuring Managerial Satisfaction: A Manual for the JSQ Technical Report II. Center of Creative Leadership. 
Colby, A., Sippola, L., \& Phelps, E. (2002.). Social responsibility and paid work in contemporary American life. In A. Rossi (Ed.), Caring and doing for others: Social responsibility in the domains of family, work, and community (463-501). Chicago: University of Chicago Press.

Connelly, C. E., \& Gallagher, D. G. (2004). Emerging trends in contingent work research. Journal of Management, 30(6). 959-983.

Davis-Blake, A., Broschak, J. P., \& George, E. (2003). Happy together? How using nonstandard workers affects exit, voice, and loyalty among standard employees. Academy of Management Journal, 46(4), 475-485.

De Witte, H., \& Naswall, K. (2003). 'Objective' vs. 'subjecti ve' job insecurity: Consequences of temporary work for job satisfaction and organizational commitment in four European countries. Economic and Industrial Democracy, 24(2), 149-188.

Deci, E. L., Connell, J. P., \& Ryan, R. M. (1989). Self-determination in a work setting. Journal of Applied Psychology, 74(4), 580-590.

Deci, E. \& Ryan, R. (1987). The support of autonomy and control of behavior. Journal of Personality and Social Psychology, 53(6),1024-1037.

Donohue, S. M., \& Heywood, J. S. (2004). Job Satisfaction and Gender: and expanded specification from the NCSY. International Journal of Manpower, 25(2), 211.

Ellingson, J. E., Gruys, M. L., \& Sackett, P. R. (1998). Factors related to the satisfaction and performance of temporary employees. Journal of Applied Psychology, 83(6), 913-921.

Farber, H. S. (2000). Alternative and part-time employment arrangements as a response to job loss. In D. Neumark (Ed.), On the job: Is long-term employment a thing of the past? (398-426). New York: Russell Sage Foundation.

Ferber, M. A., \& Waldfogel, J. (1998). The long-term consequences of nontraditional employment. Monthly Labor Review, 121(5), 3-12.

Feldman, D. C. (1990). Reconceptualizing the nature and consequences of part-time work. Academy of Management Review 15(1), 103-112.

Feldman, D. C., Doerpinghaus, H. I., \& Turnley, W. H. (1995). Employee reactions to temporary jobs. Journal of Managerial Issues, 7, 127-141.

Gist, M. E. (1987). Self-efficacy: Implications for organizational behavior and human resource management. Academy of Management Review, 12(3), 472-485. 
Gist, M. E., \& Mitchell, T. R. (1992). Self-efficacy: A theoretical analysis of its determinants and malleability. Academy of Management Review 17(2), 183-211.

Griffeth, R. W., Hom, P. W., \& Gaertner, S. (2000). A meta-analysis of antecedents and correlates of employee turnover: Update, moderator tests, and research implications for the next millennium. Journal of Management, 26(3), 463-488.

Griffith, J. (2001). Do satisfied employees satisfy customers? Support-services staff morale and satisfaction among public school administrators, students, and parents. Journal of Applied Social Psychology, 31(8), 1627-1658.

Hackman, J. R., \& Oldham, G. R. (1980). Work redesign. Reading, MA: AddisonWesley.

Harackiewicz, J. M., Sansone, C., \& Manderlink, G. (1985). Competence, achievement orientation, and intrinsic motivation: A process analysis. Journal of Personality and Social Psychology, 48(2), 493-508.

Houseman, S. N., \& Polivka, A. E. (2000). The implications of flexible staffing arrangements for job stability. In D. Neumark (Ed.), On the Job: Is Long-term Employment a Thing of the Past? (427-462). New York: Russell Sage Foundation.

laffaldano, M. T., \& Muchinsky, P. M. (1985). Job satisfaction and job performance: A meta-analysis. Psychological Bulletin, 97, 251-273.

Jones, D. (2005, May 24). Are you proud of your job? USA Today, p. B1.

Judge, T. A., Thoresen, C. J., Bono, J. E., \& Patton, G. K. (2001). The job satisfactionjob performance relationship: A qualitative and quantitative review. Psychological Bulletin, 127(3), 376-407.

Kalleberg, A. L. (2000). Nonstandard employment relations: Part-time, temporary, and contract work. Annual Review of Sociology, 26, 341-365.

Kalleberg, A. L., Reskin, B. F., \& Hudson, K. (2000). Bad jobs in America: Standard and nonstandard employment relations and job quality in the United States. American Sociological Review, 65(2), 256-278.

Koberg, C. S., Boss, R. W., Senjem, J. C., \& Goodman, E. A. (1999). Antecedents and outcomes of empowerment. Group and Organization Management, 24(1), 71-91.

Koys, D. J. (2001). The effects of employee satisfaction, organizational citizenship behavior, and turnover on organizational effectiveness: A unit-level, longitudinal study. Personnel Psychology, 54, 101-114. 
Krausz, M., Brandwein, T., \& Fox, S. (1995). Work attitudes and emotional responses of permanent, voluntary, and involuntary temporary-help employees: An exploratory study. Applied Psychology: An International Review 44, 217-232.

Levenson, A. R. (2000). Long-run trends in part-time and temporary employment: Toward an understanding. In D. Neumark (Ed.), On the job: Is long-term employment a thing of the past? (335-397). New York: Russell Sage Foundation.

Liden, R.C., Lucas, G.H., \& Sparrowe, R.T. (2000). An examination of the mediating role of psychological empowerment on the relations between the job, interpersonal relationships, and work outcomes. Journal of Applied Psychology, $85,407-416$.

Lowry, D. S., Simon, A., \& Kimberley, N. (2002). Toward improved employment relations practices of casual employees in the New South Wales registered clubs industry. Human Resource Development Quarterly, 13(1), 53-70.

MacNamara, D. (2003). Understanding boundaryless careers: Independent contractors in high tech sectors. Paper presented at the annual Academy of Management Meeting, Seattle, WA.

Marler, J. H., Barringer, M. W., \& Milkovich, G. T. (2002). Boundaryless and traditional contingent employees: Worlds apart. Journal of Organizational Behavior, 23:, 425-453.

Nollen, S., \& Axel, H. (1996). Managing contingent workers: How to reap the benefits and reduce the risks. New York: American Management Association.

Ozaralli, N. (2003). Effects of transformational leadership on empowerment and team effectiveness. Leadership \& Organization Development Journal, 24(5/6), 335345.

Pratt, M. G., \& Ashforth, B. E. (2003). Fostering meaningfulness in working and at work. In K.S. Cameron, J. E. Dutton, \& R. E. Quinn (Eds.), Positive organizational scholarship: Foundations of a new discipline (309-327), San Francisco: BerrettKoehler Publishers Inc.

Ryan, A. M., Schmit, M. J., \& Johnson, R. (1996). Attitudes and effectiveness: Examining relations at an organizational level. Personnel Psychology, 49, 853882.

Schneider, B. (1987). The people make the place. Personnel Psychology, 40(3), 437453. 
Seibert, S. E., Silver, S. R., \& Randolph, W. A. (2004). Taking empowerment to the next level: A multiple-level model of empowerment, performance, and satisfaction. Academy of Management Journal, 47(3), 332-349.

Spector, P. E. (1986). Perceived control by employees: A meta-analysis of studies concerning autonomy and participation at work. Human Relations, 39(11), 10051016.

Spreitzer, G. M. (1995). Psychological empowerment in the workplace: Dimenstions, measurement, and validation. Academy of Management Journal, 38(5), 14421466.

Spreitzer, G. M. (1996). Social structural characteristics of psychological empowerment. Academy of Management Journal, 39(2), 483-505.

Spreitzer, G. M., Kizilos, M. A., \& Nason, S. W. (1997). A Dimensional Analysis of the Relationship Between Psychological Empowerment and Effectiveness, Satisfaction, and Strain. Journal of Management, 23(5), 679-705.

Staples, L. H. (1990). Powerful ideas about empowerment. Administration in Social Work, 14(2), 29-42.

Thomas, K., \& Tymon, W. (1994). Does empowerment always work: Understanding the role of intrinsic motivation and personal interpretation. Journal of Management Systems, 6(2), 1-13.

Thomas, K. W., \& Velthouse, B. A., (1990). Cognitive elements of empowerment. Academy of Management Review 15(4), 666-681.

Tilly, C. (1992). Dualism in part-time employment. Industrial Relations, 31(2), 330-347.

Viswesvaran, C., Deshpande, S. P., \& Joseph, J. (1998). Job satisfaction as a function of top management support for ethical behavior: A study of Indian managers. Journal of Business Ethics, 17(4), 365-372.

Welch, F. (1997). Wages and participation. Journal of Labor Economics, 15(1, pt. 2), 77-103.

Wrzesniewski, A. (2003). Finding positive meaning in work. In K.S. Cameron, J. E. Dutton, \& R. E. Quinn (Eds.), Positive organizational scholarship: Foundations of a new discipline (296-308). San Francisco: Berrett-Koehler Publishers Inc.

Zimmerman, M. A. (1990). Taking aim on empowerment research: On the distinction between individual and psychological conceptions. American Journal of Community Psychology, 18(1), 169-177. 